\title{
"Structural Equation Modeling on Evaluate Validity and Reliability of the Instrument in Soft Skills Training to Enhance Employability Competency"
}

\author{
Santhosh Kumar A.V, Dinesh.N, Periasamy P
}

\begin{abstract}
A survey based design in research is followed due to numeric and accurate description of paradigms covering attitudes and opinions of the respondents. The purpose of survey research is to gather data from groups of people by utilizing a questionnaire. A questionnaire was designed for B school students titled "Perception among B School Graduates about the importance of Soft Skills Training in enhancing Employability Competency". It was to analyze the impact of soft skills training on the employability competency of $B$-School graduates. Structural Equation Modeling (SEM) was used to establish convergent validity, discriminant validity and internal consistency (reliability) of the above questionnaire before conducting the survey. Convergent validity ideally connotes to the measure of constructs to be theoretically related and actually is related. Discriminant validity on the other hand denotes the distance between items, and that they should not be too closely related to one another. Convergent validity is proven when constructs that are similar respond to one another, while Discriminant validity is said to exist if we can sufficiently differentiate two of the dissimilar constructs. Reliability refers to the confirmation of the instrument to be free from errors. Structural Equation Modeling was used to establish internal consistency, which indicates how well items score when it comes to the test of consistency against one another. The main purpose of this study was to evaluate and test the validity and reliability of the research instrument used to analyze the impact of soft skills training on the employability competency of B-School graduates
\end{abstract}

Keywords: Structural Equation Modeling (SEM), Convergent validity, Discriminant validity, Reliability, Survey Research.

\section{INTRODUCTION}

Research Methodology addresses the process of the research, describing how the research will be accomplished (Creswell, 2003). A study was undertaken to understand B-school students' perspective about the importance of soft skills training provided by educational institutions. This study also focused on impact of soft skills training on employability among the student community. The methodology used for the study included quantitative

Revised Manuscript Received on November 19, 2019

Dr. Santhosh Kumar Assistant Professor, Dept. of Management, Government First Grade College for Women, Old M.C. Road, Maddur-571428, Mandya District, Karnataka, India. (Email: sankum7578@gmail.com)

Dr. Dinesh.N, Assistant Professor, Faculty of Management Studies, CMS Business School, Jain Deemed to be University, Bangalore, Karnataka India. (Email: dinesh.rao@cms.ac.in),

Dr. Periasamy P, Associate Professor, Faculty of Management Studies, CMS Business School, Jain Deemed to be University, Bangalore, Karnataka India. ( Email: dr.periasamy_p@cms.ac.in) methods for collecting and analyzing data for the study. A survey based design was followed due to numeric and accurate description of paradigms covering attitudes and opinions of the respondents. The purpose of survey research is to gather data from groups of people by utilizing questionnaires (Ary, Jacobs \& Razavieh, 2002). The MBA students under Bangalore University, Vishveshvariah Technological University and Autonomous universities were the population for this study. Stratified Random Sampling method was used for selecting the sample for the study. A sample of 3 Universities i.e. Bangalore University, Vishveshvariah Technological University and Autonomous universities with 1193 B-School Students with reference to Bangalore was taken as a representative for conducting the study.

A questionnaire was designed for B school students titled "Perception among B School Graduates about the importance of Soft Skills Training in enhancing Employability Competency". Section B of the questionnaire was adapted from the instrument (Human Resource Soft Skills Survey HRSSS) developed by Fernando Cortez (2014) in a study of utilization of soft skills in retention of professionals at Texas, U.S.A. Section $\mathrm{C}$ of the questionnaire was adapted from various instruments in the manual "Collecting Evaluation Data: End- of Session Questionnaires" formulated by Ellen -Taylor Powell and Marcus Renner (2009) at Wisconsin, U.S.A. The questionnaire for students comprised of four sections: Section A: Student Background/Demographics which included demographic data; Section B: Student perception about soft skills important for employability and the level of soft skills training provided in B schools; Section C: Focused on soft skills training evaluation \& outcomes and Section D: Opened-ended questions - respondents had the opportunity to indicate the challenge in soft skills development, integration of any other technique in soft skills training program and any additional comments that the respondent felt would be pertinent to this study. The demographic data in Section A included variable such as age, gender etc. In Section B, an instrument to capture data on a five point Likert scale has been given where respondents were instructed to rate the soft skill (13 soft skill types) important 


\section{"Structural Equation Modeling on Evaluate Validity and Reliability of the Instrument in Soft Skills Training to Enhance Employability Competency"}

for employability based on the following scale: Ranging from strongly agree to strongly disagree with neutral and other points such as agree and disagree placed accordingly. The responses were taken according to respondent's choice on the level of soft skills training (13 soft skill types) provided in B schools based on the following scale: Very Great Extent = VG.Ext; Considerable Extent $=$ C.Ext; Some Extent $=$ S.Ext; Very Little Extent $=$ VL.Ext; No Extent $=$ N.Ext. In Section $\mathrm{C}$, the instrument comprising a five point Likert scale was constructed mandating the respondents to evaluate the soft skills training program (30 Statements) in their respective colleges and also it's outcomes based on the continuum from strongly agree to strongly disagree. Section D consisted of five open ended questions to elicit qualitative data about aspects pertaining to the study. Structural Equation Modeling was used to establish convergent validity, discriminant validity and internal consistency (reliability) of the above questionnaire before conducting the survey.

\section{REVIEW OF LITERATURE}

The literature to be reviewed contains all the available ma terial in this field of study. Several sources such as books, a rticles, newspapers, research papers, newspapers and magazi nes have been reviewed for this study.

$>$ According to Ringle et al. (2005), partial least square based structural equation model is used to a large extent in recent times after the development of a software named SMART-PLS.

$>$ According to Creswell (2003), researcher uses post positivist claims for developing knowledge through quantitative means. It involves thinking on the basis of cause and effect, deducing variables from generic to specific, formulating research questions, developing hypotheses, choosing the right measure and finally employing the means of inquiry such as survey based or experimental design.

$>$ According to Ary, Jacobs \& Razavieh (2002), validity represents the capacity of an instrument/ questionnaire to ascertain what it claims to measure.

$>$ According to Ary et al. (2002), reliability refers to the confirmation of the instrument to be free from errors.

$>$ According to Borg and Gall (1996), "The purpose of a survey is to use questionnaires or interviews to collect data from respondents in a sample about their characteristics, perceptions and opinions to generalize the results to a population that the sample is intended to represent. The study model is organized and standardized by a survey or questionnaire. It also offers the opportunity to gather great lovers

$>$ According to L.R. Gay (1996), validity is the ability where we investigate if the instrument measures what it intends to measure.

$>$ According to Krathwohl (1988) "A questionnaire collects inexpensively large amounts of data from many respondents".

\section{OBJECTIVES OF THE STUDY}

- To evaluate and test the validity of the research instrument used.

- To evaluate and test the reliability of the research instrument used.

\section{APPLICATION OF STRUCTURAL EQUATION \\ MODELING TO EVALUATE VALIDITY AND RELIABILITY OF THE RESEARCH INSTRUMENT}

Structural Equation Modeling is used in research to test the theoretical constructs which are complex. Structural Equation Modeling can be divided into two parts. The measurement model is the part which relates measured variables to latent variables. The structural model is the part that relates latent variables to one another. The advantage of Structural Equation Modeling is that it will infuse each measure and structural model at the same time. Besides this, analysis is created on multiple freelance and dependent variables within the kind of each latent and manifest constructs. In Structural Equation Modeling, measure Model is delineate as 'Outer Model' and Structural Model is delineate as 'Inner Model'. Partial Least sq. based mostly structural equation model is employed to an outsized extent in recent times when the event of a software system named SMART-PLS by Ringle et al. (2005). Using SMART-PLS, along with the model testing, reliability and validity of the instruments can be checked. In this study, Structural Equation Modeling was used for the purpose of checking the reliability and validity of the instrument used. In the measurement model, the internal consistency, convergent validity and discriminant validity of the constructs were checked. Validity is the ability where we investigate if the instrument measures what it intends to measure. Validity represents the capacity of an instrument/ questionnaire to ascertain what it claims to measure. Structural Equation Modeling was used to establish convergent and discriminant validity which are both considered as subcategories of construct validity. Convergent validity ideally connotes to the measure of constructs to be theoretically related and actually is related. Discriminant validity on the other hand denotes the distance between items, and that they should not be too closely related to one another. Convergent validity is proven when constructs that are similar respond to one another, while Discriminant validity is said to exist if we can sufficiently differentiate two of the dissimilar constructs. Reliability refers to the confirmation of the instrument to be free from errors. Structural Equation Modeling was used to establish internal consistency, which indicates how well items score when it comes to the test of consistency against one another. 


\section{ANALYSIS \& INTERPRETATION}

Table 1 Table Constructs and Item Description

\begin{tabular}{|c|c|c|}
\hline Constructs & $\begin{array}{l}\text { Item } \\
\text { Code }\end{array}$ & Item \\
\hline \multirow{3}{*}{$\begin{array}{l}\text { Social skills provided in } \\
\text { college }\end{array}$} & Q2a & Communication Skills \\
\hline & $\mathrm{Q} 2 \mathrm{~b}$ & Team Work Skills \\
\hline & Q2c & Presentation Skills \\
\hline \multirow{10}{*}{$\begin{array}{lr}\text { Personal } & \text { and } \\
\text { Methodological } & \text { skills } \\
\text { provided in college } & \end{array}$} & Q2d & Professionalism \\
\hline & Q2e & Inter - Personal Skills \\
\hline & Q2f & Time Management Skills \\
\hline & Q2g & Stress Management Skills \\
\hline & Q2h & Problem Solving Skills \\
\hline & $\mathrm{Q} 2 \mathrm{i}$ & Decision Making Skills \\
\hline & $\mathrm{Q} 2 \mathrm{j}$ & Leadership Skills \\
\hline & Q2k & Self-Management Skills \\
\hline & Q21 & Project Management Skills \\
\hline & Q2m & Etiquette (Professional Grooming, Manners etc) \\
\hline \multirow{3}{*}{$\begin{array}{l}\text { Institutional planning of } \\
\text { soft skills }\end{array}$} & Q3f & $\begin{array}{l}\text { Soft Skills needs are assessed systematically ( by placement cell in } \\
\text { the college ) }\end{array}$ \\
\hline & Q3g & Training objectives for each topic are fixed and implemented \\
\hline & Q3h & $\begin{array}{l}\text { Content is organized and } \\
\text { easy to follow }\end{array}$ \\
\hline \multirow{4}{*}{$\begin{array}{l}\text { Soft skills content and } \\
\text { facilities }\end{array}$} & Q3i & $\begin{array}{l}\text { Content is updated based on } \\
\text { present industry needs }\end{array}$ \\
\hline & Q3j & $\begin{array}{l}\text { Soft Skills Training integrates theoretical basic concepts with real } \\
\text { world applications ( Practical Orientation ) }\end{array}$ \\
\hline & Q3k & $\begin{array}{l}\text { Materials distributed are pertinent } \\
\text { and useful. }\end{array}$ \\
\hline & Q3m & $\begin{array}{l}\text { Training is held during convenient } \\
\text { time and place }\end{array}$ \\
\hline \multirow{6}{*}{ Trainer evaluation } & Q3p & Soft skills trainer presents the content with clarity \\
\hline & $\mathrm{Q} 3 \mathrm{q}$ & Trainer is Knowledgeable \\
\hline & Q3s & Class participation and interaction is encouraged during sessions \\
\hline & Q3t & Trainer collects the feedback at the end of the program \\
\hline & Q3u & Soft Skills training given is according to my expectations \\
\hline & Q3v & $\begin{array}{l}\text { College should place greater emphasis on developing soft skills in } \\
\text { students }\end{array}$ \\
\hline \multirow{8}{*}{$\begin{array}{l}\text { Impact of soft skills } \\
\text { training on employability }\end{array}$} & Q3aa & $\begin{array}{l}\text { Soft skills Training has enhanced } \\
\text { self-awareness }\end{array}$ \\
\hline & Q3ab & Soft Skills Training has improved my confidence levels and attitude \\
\hline & Q3ac & $\begin{array}{l}\text { Soft skills Training has helped me prepare for the process of job } \\
\text { search }\end{array}$ \\
\hline & Q3ad & $\begin{array}{l}\text { Soft skills Training has helped me in preparing for future job } \\
\text { interviews with confidence }\end{array}$ \\
\hline & Q3ae & $\begin{array}{l}\text { Soft skills Training has helped me to prepare for seeking } \\
\text { employment }\end{array}$ \\
\hline & Q3x & $\begin{array}{l}\text { Soft Skills Training has helped me to improve Social Skills } \\
\text { (Communication Skills, Team Work Skills, Leadership Skills) }\end{array}$ \\
\hline & Q3y & $\begin{array}{l}\text { Soft Skills Training has helped me to improve Personal Skills } \\
\text { (Stress Management Skills, Time Management Skills, } \\
\text { Professionalism) }\end{array}$ \\
\hline & Q3z & $\begin{array}{l}\text { Soft Skills Training has helped me to improve Methodological } \\
\text { Skills ( Decision Making Skills, Problem Solving Skills ) }\end{array}$ \\
\hline
\end{tabular}


"Structural Equation Modeling on Evaluate Validity and Reliability of the Instrument in Soft Skills Training to Enhance Employability Competency"

Chart 1

Measurement Model - Perception of Students

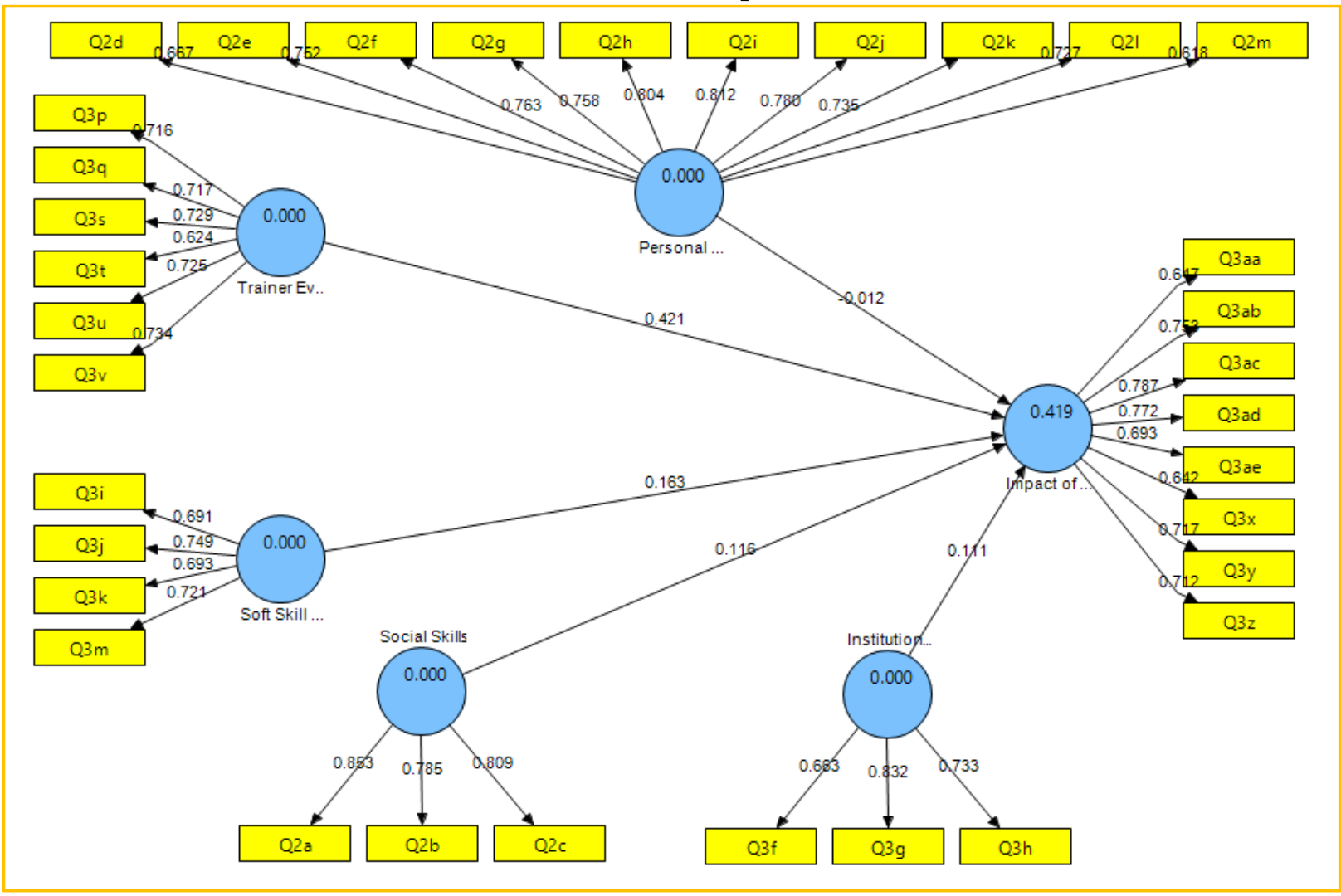

Table 2

Internal Consistency and Convergent Validity

\begin{tabular}{|c|c|c|c|c|c|}
\hline $\begin{array}{l}\text { First Order } \\
\text { Constructs }\end{array}$ & Items & $\begin{array}{l}\text { Outer } \\
\text { Loadings }\end{array}$ & $\begin{array}{l}\text { Cronbach's } \\
\text { Alpha }\end{array}$ & $\begin{array}{l}\text { Composite } \\
\text { Reliability }\end{array}$ & AVE \\
\hline \multirow{3}{*}{$\begin{array}{l}\text { Social skills } \\
\text { provided in College }\end{array}$} & Q2a & 0.85 & \multirow{3}{*}{0.75} & \multirow{3}{*}{0.86} & \multirow{3}{*}{0.67} \\
\hline & Q2b & 0.78 & & & \\
\hline & Q2c & 0.81 & & & \\
\hline \multirow{10}{*}{$\begin{array}{l}\text { Personal and } \\
\text { Methodological } \\
\text { skills provided in } \\
\text { college }\end{array}$} & Q2d & 0.67 & \multirow{10}{*}{0.91} & \multirow{10}{*}{0.92} & \multirow{10}{*}{0.55} \\
\hline & Q2e & 0.75 & & & \\
\hline & Q2f & 0.76 & & & \\
\hline & Q2g & 0.76 & & & \\
\hline & Q2h & 0.80 & & & \\
\hline & Q2i & 0.81 & & & \\
\hline & $\mathrm{Q} 2 \mathrm{j}$ & 0.78 & & & \\
\hline & Q2k & 0.74 & & & \\
\hline & Q21 & 0.73 & & & \\
\hline & $\mathrm{Q} 2 \mathrm{~m}$ & 0.62 & & & \\
\hline
\end{tabular}




\begin{tabular}{|c|c|c|c|c|c|}
\hline \multirow{3}{*}{$\begin{array}{l}\text { Institutional } \\
\text { planning of soft } \\
\text { skills }\end{array}$} & Q3f & 0.66 & \multirow{3}{*}{0.71} & \multirow{3}{*}{0.79} & \multirow{3}{*}{0.56} \\
\hline & Q3g & 0.83 & & & \\
\hline & Q3h & 0.73 & & & \\
\hline \multirow{4}{*}{\begin{tabular}{lr}
\multicolumn{1}{c}{ Soft } & skills \\
content & and \\
facilities &
\end{tabular}} & Q3i & 0.69 & \multirow{4}{*}{0.73} & \multirow{4}{*}{0.81} & \multirow{4}{*}{0.51} \\
\hline & Q3j & 0.75 & & & \\
\hline & Q3k & 0.69 & & & \\
\hline & $\mathrm{Q} 3 \mathrm{~m}$ & 0.72 & & & \\
\hline \multirow{6}{*}{$\begin{array}{l}\text { Trainer } \\
\text { evaluation }\end{array}$} & $\mathrm{Q} 3 \mathrm{p}$ & 0.72 & \multirow{6}{*}{0.80} & \multirow{6}{*}{0.86} & \multirow{6}{*}{0.50} \\
\hline & $\mathrm{Q} 3 \mathrm{q}$ & 0.72 & & & \\
\hline & Q3s & 0.73 & & & \\
\hline & Q3t & 0.62 & & & \\
\hline & $\mathrm{Q} 3 \mathrm{u}$ & 0.73 & & & \\
\hline & Q3v & 0.73 & & & \\
\hline \multirow{8}{*}{$\begin{array}{l}\text { Impact of soft } \\
\text { skills training on } \\
\text { employability }\end{array}$} & Q3aa & 0.65 & \multirow{8}{*}{0.86} & \multirow{8}{*}{0.89} & \multirow{8}{*}{0.51} \\
\hline & Q3ab & 0.75 & & & \\
\hline & Q3ac & 0.79 & & & \\
\hline & Q3ad & 0.77 & & & \\
\hline & Q3ae & 0.69 & & & \\
\hline & Q3x & 0.64 & & & \\
\hline & Q3y & 0.72 & & & \\
\hline & Q3z & 0.71 & & & \\
\hline
\end{tabular}

\section{Internal Consistency}

Internal consistency of the constructs can be referred from the Cronbach alpha and Composite reliability values. A threshold value of 0.7 was used for confirming the reliability of the variables under consideration in the research as stated by Nunnally (1978). It was found from the table that all the sub-constructs have Cronbach values greater than 0.7. Further, to ensure the internal consistency, the Composite reliability value is also considered. The Composite reliability value ranges between 0.79 to 0.92 which is also above the threshold level of 0.70 . Hence, we can conclude that there are no issues relating to internal consistency with respect to the instrument.

\section{Convergent Validity}

Convergent validity can be assessed by observing the Outer loadings score and the Average Variance Extracted (AVE). The AVE value for the constructs ranges between 0.50 to 0.67 which is found to be greater than the cut-off value of 0.5 as suggested by Hair et al. (2014). Based on the output it is confirmed that the constructs do not have any convergent validity issues.

Table 3Correlation matrix and square root of AVE

\begin{tabular}{|l|l|l|l|l|l|l|}
\hline Constructs & $\mathbf{1}$ & $\mathbf{2}$ & $\mathbf{3}$ & $\mathbf{4}$ & $\mathbf{5}$ & $\mathbf{6}$ \\
\hline $\begin{array}{l}\text { Impact of soft skills training } \\
\text { on employability }\end{array}$ & $\mathbf{0 . 7 2}$ & & & & & \\
\hline Institutional planning of soft skills & 0.43 & $\mathbf{0 . 7 5}$ & & & & \\
\hline Personal and Methodological skills provided in college & 0.36 & 0.33 & $\mathbf{0 . 8 2}$ & & & \\
\hline Social skills provided in college & 0.30 & 0.36 & 0.58 & $\mathbf{0 . 7 4}$ & & \\
\hline Soft skills content and facilities & 0.49 & 0.50 & 0.34 & 0.33 & $\mathbf{0 . 7 1}$ & \\
\hline Trainer evaluation & 0.60 & 0.48 & 0.39 & 0.37 & 0.55 & $\mathbf{0 . 7 1}$ \\
\hline
\end{tabular}


"Structural Equation Modeling on Evaluate Validity and Reliability of the Instrument in Soft Skills
Training to Enhance Employability Competency"

Note: Square root of AVE is represented as bold in the diagonal format

Table 4Factor Loadings and Cross-Loadings

\begin{tabular}{|c|c|c|c|c|c|c|}
\hline Items & $\begin{array}{l}\text { Impact of soft } \\
\text { skills training on } \\
\text { employability }\end{array}$ & $\begin{array}{l}\text { Institutional } \\
\text { planning of } \\
\text { soft skills }\end{array}$ & $\begin{array}{l}\text { Personal and } \\
\text { Methodological } \\
\text { Skills provided in } \\
\text { college }\end{array}$ & $\begin{array}{l}\text { Social } \\
\text { Skills } \\
\text { provided } \\
\text { in college }\end{array}$ & $\begin{array}{l}\text { Soft Skills } \\
\text { Content } \\
\text { and } \\
\text { Facilities }\end{array}$ & $\begin{array}{l}\text { Trainer } \\
\text { Evaluation }\end{array}$ \\
\hline Q3aa & 0.65 & 0.38 & 0.27 & 0.25 & 0.38 & 0.35 \\
\hline Q3ab & 0.75 & 0.31 & 0.29 & 0.20 & 0.32 & 0.50 \\
\hline Q3ac & 0.79 & 0.35 & 0.28 & 0.20 & 0.35 & 0.48 \\
\hline Q3ad & 0.77 & 0.30 & 0.25 & 0.21 & 0.38 & 0.48 \\
\hline Q3ae & 0.69 & 0.30 & 0.25 & 0.16 & 0.35 & 0.43 \\
\hline Q3x & 0.64 & 0.25 & 0.23 & 0.22 & 0.31 & 0.43 \\
\hline Q3y & 0.72 & 0.30 & 0.24 & 0.21 & 0.33 & 0.39 \\
\hline Q3z & 0.71 & 0.26 & 0.27 & 0.29 & 0.37 & 0.38 \\
\hline Q3f & 0.26 & 0.66 & 0.23 & 0.24 & 0.29 & 0.32 \\
\hline Q3g & 0.37 & 0.83 & 0.25 & 0.30 & 0.42 & 0.40 \\
\hline Q3h & 0.31 & 0.73 & 0.26 & 0.27 & 0.40 & 0.34 \\
\hline Q2a & 0.34 & 0.30 & 0.85 & 0.44 & 0.31 & 0.34 \\
\hline Q2b & 0.27 & 0.24 & 0.78 & 0.48 & 0.24 & 0.33 \\
\hline Q2c & 0.26 & 0.25 & 0.81 & 0.52 & 0.28 & 0.26 \\
\hline Q2d & 0.16 & 0.25 & 0.43 & 0.67 & 0.20 & 0.23 \\
\hline Q2e & 0.24 & 0.19 & 0.44 & 0.75 & 0.23 & 0.30 \\
\hline Q2f & 0.25 & 0.20 & 0.42 & 0.76 & 0.26 & 0.30 \\
\hline Q2g & 0.20 & 0.33 & 0.36 & 0.76 & 0.30 & 0.26 \\
\hline Q2h & 0.22 & 0.29 & 0.45 & 0.80 & 0.24 & 0.32 \\
\hline Q2i & 0.23 & 0.31 & 0.40 & 0.81 & 0.22 & 0.27 \\
\hline Q2j & 0.25 & 0.25 & 0.46 & 0.78 & 0.22 & 0.25 \\
\hline Q2k & 0.18 & 0.29 & 0.49 & 0.74 & 0.30 & 0.30 \\
\hline Q21 & 0.30 & 0.34 & 0.47 & 0.73 & 0.23 & 0.30 \\
\hline $\mathrm{Q} 2 \mathrm{~m}$ & 0.15 & 0.28 & 0.38 & 0.62 & 0.26 & 0.17 \\
\hline Q3i & 0.31 & 0.42 & 0.15 & 0.21 & 0.69 & 0.32 \\
\hline Q3j & 0.39 & 0.31 & 0.25 & 0.24 & 0.75 & 0.40 \\
\hline Q3k & 0.31 & 0.33 & 0.30 & 0.26 & 0.69 & 0.37 \\
\hline $\mathrm{Q} 3 \mathrm{~m}$ & 0.36 & 0.38 & 0.28 & 0.23 & 0.72 & 0.46 \\
\hline Q3p & 0.43 & 0.35 & 0.29 & 0.21 & 0.42 & 0.72 \\
\hline $\mathrm{Q} 3 \mathrm{q}$ & 0.40 & 0.25 & 0.33 & 0.27 & 0.40 & 0.72 \\
\hline Q3s & 0.42 & 0.27 & 0.29 & 0.25 & 0.36 & 0.73 \\
\hline Q3t & 0.44 & 0.38 & 0.23 & 0.30 & 0.38 & 0.62 \\
\hline $\mathrm{Q} 3 \mathrm{u}$ & 0.44 & 0.31 & 0.24 & 0.24 & 0.36 & 0.73 \\
\hline Q3v & 0.44 & 0.44 & 0.27 & 0.29 & 0.42 & 0.73 \\
\hline
\end{tabular}

personal and methodological skills provided in college, social skills provided in college, impact of soft skills training on employability, trainer evaluation, soft skills content, facilities and institutional planning of soft skills) revealed that positive correlation exists between the study variables from the perspective of students. While looking at the results from an in-depth perspective, the independent variables considered in the study namely social skills provided in college, institutional planning of soft skills, soft skills content, facilities and trainer evaluation were found to have significant positive relationship with the dependent variable employability competency.

Findings from Structural Equation Modeling using SMART - PLS showed that the instrument for students is reliable as the internal consistency referred from the Cronbach alpha (all the sub constructs have Cronbach values greater than 0.7.) and

The analysis of correlation between the study variables (importance of personal and methodological skills for employability, importance of social skills for employability, 
Composite reliability values (between 0.79 to 0.92 ) is meeting the threshold value. It was also found that instrument is valid as the convergent validity (AVE value for the constructs ranges between 0.50 to 0.67 which is greater than the cut-off value of 0.5 ) and discriminant validity (Items loaded on the respective constructs and squar e root of AVE were lower than correlation values for all con structs) is lacking.

\section{SUGGESTIONS}

$>$ Instrumentation in research is a critical process which requires the researcher to verify the accuracy and capacity of an instrument/ questionnaire to ascertain what it claims to measure.

The instrument should include specific instructions in each section to facilitate accuracy in responses from respondents.

A panel of subject matter experts (SMEs) can be asked to evaluate and critique the instrument before conducting the survey.

The observations, additional inputs and other suggestions of each panel member can be duly considered and incorporated into the creation of the final instrument.

$>$ Structural Equation Modeling (Measurement Model) can be used to establish convergent validity, discriminant validity and internal consistency with respect to the instrument.

Developing instructions and non- ambiguous questions in the survey instrument helps to control the degree and presence of measurement error. Minimizing or eliminating these sources of error should be addressed during the development of the survey instrument.

\section{CONCLUSION}

A researcher uses post positivist claims for developing knowledge through quantitative means. It involves thinking on the basis of cause and effect, deducing variables from generic to specific, formulating research questions, developing hypotheses, choosing the right measure and finally employing the means of inquiry such as survey based or experimental design.

The study typically is organized and standardized by a sur vey or questionnaire. It also offers most respondents the opp ortunity to collect large amounts of data many respondents. It is important that the researcher verifies the precision and capacity of an instrument/ questionnaire to ascertain what it claims to measure before conducting the survey in order to facilitate accuracy in responses from respondents and eliminate measurement errors. The researcher has various tools for this purpose and Structural Equation Modeling (SEM) is one of them, which can be used for checking the reliability and validity of the instrument used in the study.

\section{REFERENCES}

1. Ary, Donald., Jacobs, Lucy Cheser., Razavieh, Asghar. (2002). "Introduction for Research in Education", 6th edition, Belmont: CA Wadswarth.

2. C.Ringle., S.Wende., A.Will. (2005). "Smart-PLS Version 2.0 M3", Retrieved on March 26, 2015 from http://www.smartpls.de.

3. Creswell, John W. (2003). "Research Design: Qualitative, Quantitative and Mixed Method Approaches", 2nd edition, New York: Sage Publications.

4. Fornell, C., Larcker, D. (1981), "Evaluating Structural Equation Models with Unobservable Variables and Measurement Error", Journal of Marketing Research, vol. 18, issue 3, pp 39-50.

5. Hair, JF., Hult., G.T.M., Ringle, C., Sarstedt, M. (2016), "A Primer on Partial Least Squares Structural Equation Modeling (PLS-SEM)”, 2nd edition, Thousand Oaks, CA: Sage Publications.

6. Ken Kwong-Kay Wong. (2013). "Partial least square structural equation modeling (PLS-SEM) techniques using SmartPLS", Retrieved on November 10, 2015 from http:// www.researchgate.net/publication/268449353.

7. Krathwohl, D. R. (1988). "How to prepare a research proposal: Guidelines for funding and dissertations in the social and behavioral sciences", Syracuse, N.Y: Syracuse University Press, pp 361.

8. Meredith, D., Borg, Walter, R., Gall, Joyce P. (1996). "Educational Research: An Introduction", 6th edition, New York: Longman.

9. Nunnally, J. O., (1978). "Psychometric Theory"; 1st edition, New York: McGraw-Hill Publications.

\section{AUTHORS PROFILE}

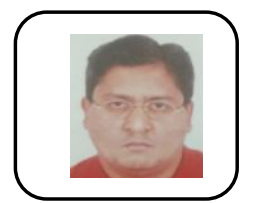

Dr. Santhosh Kumar A V, MBA, UGC NET, Ph.D, Assistant Professor, Dept. of Management, Government First Grade College for Women Maddur , 15 years of Experience

sankum7578@gmail.com,

Dr. Santhosh Kumar A V is a doctorate in Management (Human Resource), had qualified in UGC's-National Eligibility Test in 2011 and authored Nine books, having academic and industrial blend as a unique quality, 3 years of various industry and 12 years of teaching the Management subjects.

He has published Twenty papers in International and National Journals with High Impact Factor and made Ten conference presentations, and attended more than 40 Faculty Development workshop. Member of various university as Board of Studies.

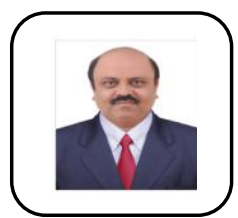

Dr. Dinesh.N, MCom, MHRM, MLM, Ph.D. Assistant Professor, OB and HR CMS Jain deemed to be University, Bangalore $10+$ years of Experience in industry and $14+$ years of Experience in teaching dinesh.rao@cms.ac.in

Dr. Dinesh.N is a doctorate in Management (Human Resource), having academic and industrial blend as a unique quality, 10 years of various industry and 14 years of teaching the Management subjects authored Six books. He has published Twenty papers in International and National Journals with Four Scopus journal publication and made Ten conference presentations, and attended more than 60 Faculty Development workshop. Chaired as Conference chair and speaker at National conference, Member of various International and National journal, Member of various university as Board of Examiner and Board of Studies.

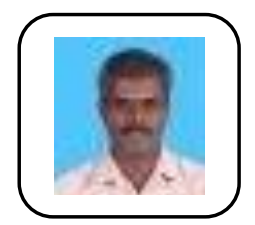

Dr.P. Periasamy, MBA, M. Phil, UGC-NET, Ph.D., Associate Professor Finance 23 years of Experience Dr.periasamy_p@cms.ac.in

Dr.P. Periasamy is a doctorate in Finance and marketing, had qualified in UGC's-National Eligibility Test in 2003 and 2004, authored two books, having academic and industrial blend as a unique quality, 4 years of various industry and 16 years of teaching the Management subjects.

He has published twenty-two Journals and made twenty-eight conference presentations. Life member of MISTE, AIMS, Exclusive MBA Global, Indian Solidarity Council of India, International. Institute of Education and Management at the national level. Member of IAAP - International. Association of Administrative Professionals., AFA-American Finance Association, AFP-

Association for Financial Professionals, IARCP - International Association of Risk \&amp; compliance. Professionals, APBM - Association of professionals in business management, STMP - Society of Technical and Management Professionals at the International level. Recipient of Awards like, Rashtriya Vidya Gaurav Puraskar Award, Rashtriya Vidya Gaurav Gold Medal Award, teaching marathon Award for "long term service" Radhakrishnan Award for "Importing knowledge".

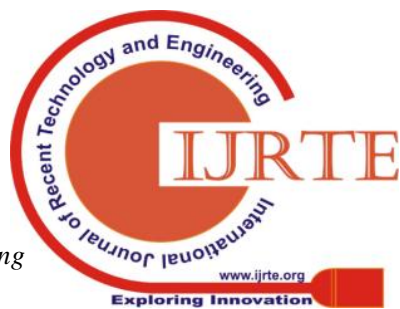

